\title{
A Review on Recycling of Sunflower Residue for Sustaining Soil Health
}

\author{
Subhash Babu, ${ }^{1}$ D. S. Rana, ${ }^{2}$ G. S. Yadav, ${ }^{3}$ Raghavendra Singh, ${ }^{1}$ and S. K. Yadav ${ }^{4}$ \\ ${ }^{1}$ ICAR Research Complex for NEHR, Sikkim Centre, Tadong, Gangtok, East Sikkim 737102, India \\ ${ }^{2}$ Indian Agricultural Research Institute, New Delhi 110012, India \\ ${ }^{3}$ ICAR Research Complex for NEHR, Tripura Centre, Lembucherra, West Tripura 799210, India \\ ${ }^{4}$ Central Potato Research Station, Shillong 793009, India \\ Correspondence should be addressed to Subhash Babu; subhiari@gmail.com
}

Received 31 July 2013; Revised 10 December 2013; Accepted 10 December 2013; Published 4 February 2014

Academic Editor: Manuel Tejada

Copyright (C) 2014 Subhash Babu et al. This is an open access article distributed under the Creative Commons Attribution License, which permits unrestricted use, distribution, and reproduction in any medium, provided the original work is properly cited.

\begin{abstract}
Modern agriculture is now at the crossroads ecologically, economically, technologically, and socially due to soil degradation. Critical analysis of available information shows that problems of degradation of soil health are caused due to imbalanced, inadequate and promacronutrient fertilizer use, inadequate use or no use of organic manures and crop residues, and less use of good quality biofertilizers. Although sizeable amount of crop residues and manure is produced in farms, it is becoming increasingly complex to recycle nutrients, even within agricultural systems. Therefore, there is a need to use all available sources of nutrients to maintain the productivity and fertility at a required level. Among the available organic sources of plant nutrients, crop residue is one of the most important sources for supplying nutrients to the crop and for improving soil health. Sunflower is a nontraditional oil seed crop produced in huge amount of crop residue. This much amount of crop residues is neither used as feed for livestock nor suitable for fuel due to low energy value per unit mass. However, its residue contains major plant nutrients in the range from 0.45 to $0.60 \%$ $\mathrm{N}, 0.15$ to $0.22 \% \mathrm{P}$, and 1.80 to $1.94 \% \mathrm{~K}$ along with secondary and micronutrients, so recycling of its residue in the soil may be one of the best alternative practices for replenishing the depleted soil fertility and improving the physical, chemical, and biological properties of the soil in the present era of production. However, some researchers have reported allelopathic effects of sunflower residue on different crops. So, selection of suitable crops and management practices may play an important role to manage the sunflower residue at field level.
\end{abstract}

\section{Introduction}

Nowadays, modern agriculture is facing the problem of land and water degradation, environmental pollution, lowering of water table, and global competition. There is a decrease in factor productivity, development of multinutrient deficiency, build of obnoxious weeds and pests, and increasing cost of production over the last two decades. This means that modern agriculture is now at the crossroads ecologically, economically, technologically, and socially; our present growth rate in agriculture is not keeping pace with the population growth rate. Our greatest living industry is in distress. Increasing the productivity and profitability of small farmers in an economically sustainable manner is the most effective step for reducing poverty and hunger in our country. The major pathway has to be productivity enhancement. Among the various reasons for this alarming situation, physical, chemical, and biological deterioration of soil ranks at the top. Critical analysis of available information shows that problems of degradation of soil health are caused due to imbalanced, inadequate and promacronutrient fertilizer use, inadequate use or no use of organic manures and crop residues, and less use of good quality bio-fertilizers. With intensive cropping, nutrient removal by crops from soil $(34 \mathrm{mt})$ has far exceeded replenishment $(18 \mathrm{mt})$. Present estimates show a deficit of $16 \mathrm{mt}$ of plant nutrients, which is likely to grow further with intensification in agriculture and increasing soil degradation. The fertilizer consumption ratio of $8.9: 2.8: 1.0$ as against $4: 2: 1$ indicates an erratic and imbalanced fertilizer use, causing decline in soil fertility and productivity. The imbalance use of fertilizer has also been responsible for low fertilizer response. Even if, so-called 
balanced fertilization emphasis on NPK will not be able to sustain high productivity. Multi-nutrient deficiency including micronutrients is becoming very common. Therefore, there is a need to use all available sources of nutrients to maintain the productivity and fertility at a required level. The degradation of soil fertility owing to over mining of nutrients and inadequate replenishment through fertilizers and other sources can only be curbed through adoption of INM technology. Among the available organic sources of plant nutrients, crop residue is one of the most important sources for supplying nutrients to the crop and for improving soil health. Integrated nutrient management based on low cost and locally available organic sources is more rational, sustainable, and economical. Amongst the nine oilseed crops, sunflower (Helianthus annuus L.) has the potential and can play an important role in meeting out shortage of oilseeds in the country. Sunflower (Helianthus annuus L.) is a nontraditional crop introduced in India during the year 1969. It now occupies an important place in all agroclimatic zones. It holds a great promise because of its short duration, photo insensitivity, and wide adaptability to different agroclimatic regions and soil types. It can be grown at any time of the year and can serve as an ideal crop during the period when the land is otherwise fallow. From the 1500 ha in 1972-73, its area increased to $2.35 \mathrm{mha}$ in 2007-08. Spring sunflower in the north-west part of India has potential to yield 4$6 \mathrm{t} /$ ha crop residue and $2-2.5 \mathrm{t} /$ ha seed yield and it has less water, nutrient, and other input requirement than wheat. This much amount of crop residues is neither used as feed for livestock nor suitable for fuel due to low energy value per unit mass. However, its residue contains major plant nutrients in the range from 0.45 to $0.60 \% \mathrm{~N}, 0.15$ to $0.22 \% \mathrm{P}$, and 1.80 to $1.94 \% \mathrm{~K}$ along with secondary and micronutrients, so recycling of its residue in the soil may be one of the best alternative practices for replenishing the depleted soil fertility and improving the physical, chemical, and biological properties of the soil. Some researchers have reported allelopathic effects of sunflower residue on different crops, which put a question on choice of crop after sunflower and its residue incorporation [1-3]. Schon and Einhelling [4] demonstrated that incorporation of dried sunflower leaf material into the soil inhibited germination and growth of grain sorghum. Water soluble toxic substances could leak from the plant and from decomposing residue causing allelopathic interference. Leachates from the plants have been shown to suppress seed germination and vegetative propagules and early seedling growth [5, 6] and decrease radicle growth [7]. Aqueous extract of some plants inhibits seedling growth [8], root and shoot growth [9], and germination [10] and induces mortality of plants [11]. The effects may be due to a variety of processes that may include reduced cell division in the roots, suppressed hormonal activity, reduced ion uptake, inhibition of protein synthesis, inhibition of photosynthesis and respiration, inhibition of enzyme activity, and reduced cell membrane permeability [12]. During the decomposition of crop residue, several acids and other compounds are released, which affect the soil $\mathrm{pH}$, nutrients availability, microbial population, and enzymatic activities, namely, dehydrogenase and phosphatase in soil.

\section{Effect of Sunflower Residue Recycling on Growth and Yield of Crops}

Inhibitory or stimulatory effects of crop residue on germination and establishments of crops caused by residues of either crops or weeds have led to investigation of the release of toxic or growth stimulating compounds from such residues. In this regards, residues of sunflower have been examined for their potential to reduce or stimulate the growth of succeeding crops in a system. Isidron et al. [13] reported that allelochemicals of mature maize foliage had an inhibitory effect on the sunflower, maize, and sorghum. Srisa-Ard [14] also indicated that crop residues derived from roots of both sunflower and soybean plants had significant inhibitory effects on plant height, root dry weight, top growth dry weight, and total dry weight of the sunflower plants. In a bioassay study, Ashrafi et al. [15] reported that sunflower extracts reduced wild barley hypocotyl length, hypocotyl weight, radicle weight, seed germination, and radicle length by as much as $44,58,61,69$, and $79 \%$, respectively, when compared with a water control. Increasing the water extract concentrations from 4 to $20 / 100 \mathrm{~mL}$ water of all sunflower parts significantly increased the inhibition of wild barley germination, seedling length, and weight. In Uttaranchal, Pal and Sand [16] reported that the preceding spring sunflower reduced the plant population, dry matter production, and all yield attributes of succeeding crops, that is, rice, maize, soybean, and pigeonpea. In greenhouse studies at Hissar, Narwal et al. [17] reported that among the different parts of sunflower (stem, leaf, inflorescence, and root), stems showed the highest inhibitory effect on the growth and yield of wheat, followed by the roots, leaves, and inflorescences. Increasing doses of sunflower biomass resulted in significant reductions in the seedling growth and yield of wheat. Chlorogenic acid, caffeoylquinic acid, and neochlorogenic acid in sunflower stems at varying concentrations might be responsible for reduced growth and yield in wheat. Similar results with different parts of sunflower residue on different crops in field studies were also reported by several workers ([12] on Bambara groundnut, $[18,19]$ on lobia, sorghum, bajra, and maize, [20] on mung bean and pearl millet, [21] on wheat, and [1] on black gram, green gram, red gram, finger millet, pearl millet, maize, sorghum, gingelly, and groundnut).

A study conducted by Gill and Sandhu [22] indicated that ground sunflower leaves from a matured crop incorporated into the soil (0.5-2.5\% weight/weight basis) decreased sunflower seed germination at all concentrations. However, only concentrations $>2 \% \mathrm{w} / \mathrm{w}$ decreased seed germination of the maize, cotton, pigeonpea, soybean, and pearl millet. While the shoot and root growth responses to allelopathic effects were dependent on the species, the adverse effects on growth of all the species were evident at the higher concentrations. Narwal et al. [23] reported that incorporation of wheat straw reduced the growth and yield of succeeding sorghum, pearl millet, maize, cluster bean, and cowpea. In pot studies, Narwal et al. [2,3] reported that sunflowerinfested soil, that is, from sunflower rhizospheres, inhibits the germination, growth, development, and grain yields and induced seedling mortality of all tested crops (sorghum, pearl 
millet, maize, cotton, cowpea, cluster bean, green gram, black gram, soybean, and pigeonpea).

At IARI New Delhi, Rana et al. [24] reported that sunflower as preceding crop caused 51 per cent reduction in the seed yield of chickpea compared to maize as a preceding crop. The yield-reducing effect of sunflower was not observed on wheat and Indian mustard. The adverse effect of complete sunflower residue incorporation on the productivity of succeeding crops was more compared to partial or complete residue removal, but there was gradual improvement in the yield of these crops under complete residue over the years. In the last harvest wheat and Indian mustard gave 3.61 and $1.88 \mathrm{t} / \mathrm{ha}$ seed yield under complete residue incorporation which was 13.5 and 13.2 per cent higher than seed yield recorded under complete residue removal. Kaya et al. [25] investigated the effect of biodegradation products of sunflower heads (BPSH) at various concentrations $(1.0 \%, 2.5 \%$, $10 \%$, and $100 \%$ ) on the seed germination and some growth parameters of rajmash, chickpea, and wheat and reported that the percentage of seed germination and germination index of seeds were similar between the control and $1.0 \%$ and $2.5 \%$ BPSH groups, but these values decreased at higher concentrations. On the other hand, growth of the seedlings gradually increased up to a concentration of $10 \% \mathrm{BPSH}$ and decreased at $100 \%$ concentration. As a result, at concentrations up to $10 \%$ the product was found to be beneficial for growth of plants. Mangare et al. [26] stated that incorporation of sunflower straw along with inorganic fertilizer increased the grain yield of green gram and sunflower as well as straw yield over control. The pooled analysis indicated that the highest grain yield was observed with the application of sunflower straw @ $4 \mathrm{t} / \mathrm{ha}+125 \% \mathrm{~N}+100 \% \mathrm{P}$ of RDF, followed by the application of sunflower straw @ $4 \mathrm{t} / \mathrm{ha}+100 \%$ of RDF which were found at par with former. The highest benefit cost ratio was obtained with the application of crop residues treatments as compared to control treatment. Badnur et al. [27] also found that sunflower stalks at $5 \mathrm{t} / \mathrm{ha}+$ subabul loppings $(50: 50)$ gave the highest grain yield $(1408 \mathrm{~kg} / \mathrm{ha})$, followed by recommended rate of fertilizer $(1403 \mathrm{~kg} / \mathrm{ha})$ and sunflower threshed ear heads at $5 \mathrm{t} / \mathrm{ha}+20 \mathrm{~kg} \mathrm{~N} / \mathrm{ha}(1399 \mathrm{~kg} / \mathrm{ha})$. The lowest grain yield ( $772 \mathrm{~kg} / \mathrm{ha}$ ) was recorded from sunflower stalks at $5 \mathrm{t} / \mathrm{ha}$. Treatment with sunflower threshed ear heads at $5 \mathrm{t} / \mathrm{ha}$ and recommended rate of fertilizer recorded the second highest sorghum fodder yield, 3472 and $3135 \mathrm{~kg} / \mathrm{ha}$, respectively. Sunflower threshed ear heads at $2.5 \mathrm{t} / \mathrm{ha}+$ subabul loppings at $2.5 \mathrm{t} / \mathrm{ha}$ ( $50: 50)$, sunflower stalks at $5 \mathrm{t} / \mathrm{ha}+$ subabul loppings $(50: 50)$, and sunflower threshed ear heads at $5 \mathrm{t} / \mathrm{ha}+20 \mathrm{~kg}$ $\mathrm{N} /$ ha resulted in the third highest 1,000-grain weights, 35.86, 35.47 and $35.33 \mathrm{~g}$, respectively.

\section{Effect of Sunflower Residue Recycling on Soil Biological Properties}

One of the most important challenges facing humanity today is to conserve/sustain natural resources, including soil and water, for increasing food production while protecting the environment. As the world population grows, stress on natural resources increases, making it difficult to maintain food security. Long-term food security requires a balance between increasing crop production, maintaining soil health and environmental sustainability. Sustainability of agricultural systems has become an important issue all over the world. Many issues of sustainability are related to soil quality and its change with time [28]. According to Doran and Parkin [29], soil quality is "the capacity of a soil to function within ecosystem boundaries to sustain biological productivity, maintain environmental quality, and promote plant and animal health." Soil biological activities have been suggested as one of the important indicators of soil quality [30]. Decomposition of plant residues is the microbially mediated progressive breakdown of organic material into $\mathrm{C}$ (biomass or $\mathrm{CO}_{2}$ ) and other nutrients [31]. Crop residues decompose into two distinct phases, an initial rapid phase, in which about $70 \%$ of $\mathrm{C}$ initially present in the residues is lost as $\mathrm{CO}_{2}$, followed by a slower phase during which the more resistant fraction is decomposed [32]. Immature plant residues with a high concentration of water-soluble compounds such as sugars, amino acids, and organic acids are decomposed more rapidly than mature material, which contain a higher proportion of resistant compounds such as cellulose, lignin, phenols, or waxes. Residue factors include chemical composition, $\mathrm{C} / \mathrm{N}$ ratio, lignin content, and the size of residue particles [33]. Residue $\mathrm{C} / \mathrm{N}$ ratio is a common indicator of residue quality but is not necessarily an accurate predictor of decomposition rate [34]. The incorporation of crop residues into the soil modifies its chemical and biochemical properties, including soil-enzyme activity [35-37], the behaviour of which has often been related to the amount [38-40] as well as to the type of organic matter [41, 42]. Soil enzymes play a major role in nutrient availability [43]. In soils, enzymes may be associated with viable cells, dead cells (abiontic enzymes), and cell debris and immobilized enzymes in the soil matrix [44]. Since, soilenzyme systems are associated with organic residue management, the burying of crop residues into the soil not only plays an important role in the soil's chemical and biochemical environment, but also affects the rate at which nutrients become available to crop plants as well as to other forms of life in the soil. Therefore, any management practice that influences the biological populations of soil would be expected to produce changes in soil enzyme activity levels. The effect exerted on soil-dehydrogenase and soil phosphatase depends on the type of crop residues incorporated. Dehydrogenase is considered to play an important role in the initial stages of the oxidation of soil organic matter [45] by transferring hydrogen and electrons from substrates to acceptors. Soil water content and temperature influence the dehydrogenase activity indirectly by affecting the soil oxidation-reduction status [46]. Addition of tobacco and sunflower residues in soil increases the activities of most of the soil enzymes, while tomato residues increased only the amylase and phosphodiesterase activities. As the enzyme activities were positively correlated to each other, a common source of the enzymes is suggested even though the coefficients of correlation demonstrate that only a low percentage of the variability can be ascribed to the interactions among enzyme activities [42]. Soil enzymes are used as biological indices of soil fertility under different tillage practices. Phosphatases are inducible enzymes excreted by plant roots and soil organisms, which can be stimulated 
by $\mathrm{P}$ starvation. Therefore, phosphatase activity has been regarded as an important factor in maintaining and controlling mineralization rate of soil organic $\mathrm{P}$ and a good indicator of $\mathrm{P}$ deficiency [47]. The measurements, of phosphatase enzyme activity performed during three years of study, were significantly lower in the soil under winter wheat grown in the conventional-monoculture farming system, in comparison to organic system. The significantly lower phosphatase enzyme activity in monoculture soil was related to lower microbial biomass carbon in the soil compared to organic system [48]. At Hisar, Kaur and Kapoor [49] reported that addition of $\mathrm{N}$ to residue to have a C:N ratio of $40: 1$ accelerated residue decomposition. An amount of 61 and $58.7 \%$ of incorporated sunflower residues was decomposed in 12 weeks when residues ( $\mathrm{C}: \mathrm{N}$ ratio 73.1$)$ were added at 1.5 and $3.0 \mathrm{t} / \mathrm{ha}$, respectively. The extent of decomposition increased to 66.6 and $61.1 \%$ when residues were incorporated at 1.5 and $3.0 \mathrm{t} / \mathrm{ha}$, respectively, along with $\mathrm{N}$ application to adjust $\mathrm{C}: \mathrm{N}$ ratio of residues to $40: 1$. Microbial biomass $C$ increased with residues as well as $\mathrm{N}$ application up to 3 weeks and then it declined. Dehydrogenase activity during decomposition of sunflower residues was higher in first week after that it declined. At Akola, Maharashtra, Ravankar et al. [50] reported that incubation of soil with $1 \%$ organic residues of cotton stalk, safflower straw, sorghum stubble, soybean stover, wheat straw, sugarcane trash, groundnut husk, sunflower straw, green gram stover, Parthenium with seed, grass complex with seed, and Xanthium with seed mixed showed wide variation in the rate of decomposition, $\mathrm{C}: \mathrm{N}$ ratio and microbial population at different intervals. Carbon dioxide evolution was maximum during the first 15 days and it decreased thereafter. The rate of decomposition was the highest for groundnut husk as compared to other residues. After incubation for 30 days, the lowest $\mathrm{C}: \mathrm{N}$ ratio was observed in grass complex. Fungal, bacterial, and actinomycetes populations increased at 30 days of incubation. Bacteria were predominant over fungi and actinomycetes.

\section{Effect of Sunflower Residue Recycling on Soil Chemical Properties}

A good account of work has been done on the use of crop residue to supplement the nutrient requirement of cropping system and to improve soil health. Sharma et al. [51] stated that nutrient-rich residues of the castor and sunflower are mostly burnt because of their high $\mathrm{C} / \mathrm{N}$ ratio. These high $\mathrm{C} / \mathrm{N}$ ratio residues can be recycled successfully, if they are supplemented with other low $\mathrm{C} / \mathrm{N}$-ratio farm-based organics and some chemical additives. Application of crop residues with a high $\mathrm{C}: \mathrm{N}$ ratio often leads to adverse impacts on available $\mathrm{N}$ in soil and growth of crops planted immediately after crop residue incorporation. A large number of organic compounds, particularly phenolic acid and acetic acid, are released during the decomposition of crop residues. The application of crop residues can cause short-term immobilization of both $\mathrm{P}$ and $\mathrm{S}$, particularly in aerobic soils. Crop residues contain large amounts of $\mathrm{K}$, which upon incorporation increased $\mathrm{K}$ availability in soil and helped to reduce $\mathrm{K}$ depletion from nonexchangeable $\mathrm{K}$ fraction of soil.
Long-term application of crop residues increased the organic matter, total $\mathrm{N}$ content, and availability of several nutrients in soils. The rate of increase in soil organic matter is low due to high turnover rates of $\mathrm{C}$ under tropical conditions. The increase in soil organic matter levels due to crop residue recycling was determined by the duration, amount, and quality of residue, soil type, climatic conditions, and cropping system followed. Crop residues influence the chemical and biological properties of the soil [52].

Ordonez-Fernandez et al. [53] conducted a field experiment in southern Spain and reported that the pea residue supplied the highest amount of nitrogen to the soil throughout its decomposition cycle; it lost $76.6 \%$ of its initial content in nitrogen, compared to the 48 and $56 \%$ of $\mathrm{N}$ released by wheat residues and sunflower, respectively. At the beginning of its decomposition cycle, the wheat residue had the lowest mass and gave the most cover, with values of $65 \%$, which was $8.6 \%$ and $20.2 \%$ more than the cover estimated for the pea and sunflower residues, respectively. The sunflower residue lasted longest, only losing $18 \%$ of its initial cover over 109 days of decomposition, compared to $47 \%$ of wheat and $53 \%$ for pea. The amount of carbon released was similar for the three residues and was around $500 \mathrm{~kg} / \mathrm{ha}$. Corbeels et al. [54] studied the $\mathrm{C}$ mineralization and $\mathrm{N}$ transformations during the decomposition of sunflower stalks and wheat straw with and without addition of $\left(\mathrm{NH}_{4}\right)_{2} \mathrm{SO}_{4}$ in a Vertisol. Soil samples were incubated under aerobic conditions for 224 days at $22^{\circ} \mathrm{C}$. The plant residues were added at a rate of $5.2 \mathrm{~g} / \mathrm{kg}$ soil. Nitrogen was applied at a rate of $50.7 \mathrm{mg} \mathrm{N} / \mathrm{kg}$ soil. Gross $\mathrm{N}$ immobilization and mineralization were calculated on the basis of the isotopic dilution technique. At the end of the incubation period a ${ }^{15} \mathrm{~N}$ balance was established. Respectively, 68 and $45 \%$ of the applied residue-C mineralized from the sunflower stalks and wheat straw after 224 days. Both crop residues caused losses of up to $25 \%$ of added ${ }^{15} \mathrm{~N}$ after 224 days of incubation. These ${ }^{15} \mathrm{~N}$ losses were about three times larger than in the control soil and were probably due to denitrification. The net immobilization of soil derived $\mathrm{N}$ following residue incorporation was the largest in the case of wheat straw, depleting all soil inorganic $\mathrm{N}$. In the wheat straw treatment with added $\left(\mathrm{NH}_{4}\right)_{2} \mathrm{SO}_{4}$ soil inorganic $\mathrm{N}$ remained available, resulting in an enhanced initial $\mathrm{C}$ mineralization and $\mathrm{N}$ immobilization compared to the treatment without added $\mathrm{N}$. In the case of the sunflower stalks, the high inorganic $\mathrm{N}$ content of the stalks suppressed the effects of $\mathrm{N}$ addition on $\mathrm{C}$ mineralization and $\mathrm{N}$ immobilization/mineralization. Gross N immobilization amounted to 31.9 and $28.2 \mathrm{mg} \mathrm{N} / \mathrm{g}$ added $\mathrm{C}$ after 14 days for wheat straw and sunflower stalks, respectively. At the end of the incubation, about $35 \%$ of the newly immobilized $\mathrm{N}$ was remineralized in both plant residue treatments. Gross $\mathrm{N}$ immobilization plotted against decomposed $\mathrm{C}$ suggests that fairly uniform C-N relationships exist during the decomposition of divers $\mathrm{C}$ substrates. Immobilization of available $\mathrm{N}$ and $\mathrm{P}$ during initial phase of decomposition of sunflower residue was also reported by Kaur and Kapoor [49]. Decreases in Olsen$\mathrm{P}$ in soil due to incorporation of organic manure and crop residues having wider $\mathrm{C}: \mathrm{N}$ ratio were also reported by Jalali [55]. In laboratory conditions, Das et al. [56] reported that 
incorporation of loppings of perennial pigeonpea, sorghum stover, and FYM caused initial immobilization of P. However, no P immobilization was observed with mung bean, Leucaena residues, and groundnut shells at $0.5 \mathrm{FC}$. At FC, none of the residues caused immobilization. The quantity of $P$ released was significantly related to the amount of $P$ added through residues. In contrast, Das and Puste [57] showed that the amounts of ammoniacal- $\mathrm{N}\left(\mathrm{NH}_{4}-\mathrm{N}\right)$, nitrate- $\mathrm{N}\left(\mathrm{NO}_{3}\right.$ $\mathrm{N})$, hydrolysable $\mathrm{N}(\mathrm{HL}-\mathrm{N})$, and nonhydrolysable (NHL-N) were increased for up to 60 days of soil submergence and increased further with the increase ( $1 \%$ by weight of soil) of various organic waste materials like crop residues, welldecomposed cow dung, composts, and other rural and urban wastes application. Similarly, Raut et al. [58] in his study showed that incorporation of sunflower straw @ $4 \mathrm{t} / \mathrm{ha}+\mathrm{RDF}$ @ (125\% N + 100\% P) in green gram recorded significantly higher soil nitrogen, phosphorus, and potassium content in green gram-sunflower sequence. Content of micronutrient ( $\mathrm{Zn}, \mathrm{Fe}, \mathrm{Cu}, \mathrm{Mn}, \mathrm{B}$, and $\mathrm{Mo}$ ) including sulphur was also maximum with the incorporation of sunflower straw @ $4 \mathrm{t} / \mathrm{ha}$ + RDF @ (125\% N + 100\% P) in green gram. Similar results were obtained by Santamaría et al. [59] with the incorporation of sunflower hulls, a residue of oil industries, in the upper layer of soil as organic amendment. In contrast, Jalali and Ranjbar [60] observed that the rates of $\mathrm{P}$ release of the residues (sunflower and wheat) were considerably higher during the first 4 weeks of incubation than during the second phase of incubation (weeks 5-12). Phosphorus release by residues was similar to the decomposition pattern. They also opined that residue $\mathrm{P}$ content was correlated with $\mathrm{P}$ release, but not with decomposition rate. Gong et al. [61] reported that sunflower oil residue incorporation in soil decreases the soil pH. In another study Badnur et al. [27] reported that incorporation of sunflower residues either with subabul loppings or inorganic $\mathrm{N}$ recorded higher available nutrients than incorporation of sunflower residues alone. However, available $\mathrm{N}$ and $\mathrm{K}$ were highest with sunflower threshed ear heads at 2.5 t/ha + subabul loppings @ 2.5 t/ha (50:50), (222 and $450 \mathrm{~kg} / \mathrm{ha}$, resp.), while available $\mathrm{P}$ was highest upon treatment with sunflower stalks at $5 \mathrm{t} / \mathrm{ha}+$ subabul loppings (50:50), (24.7 kg/ha). In maize-wheat cropping system at Kanpur, Prasad et al. [62] found that application of FYM and gypsum reduced soil $\mathrm{pH}$ by 0.38 and 0.30 units, EC by 0.07 and 0.06 units than their initial values of 7.8 and 0.37 , respectively. Organic carbon increased by 22.6 and $15.1 \%$, available $\mathrm{N}$ increased by 41.2 and $29.1 \%$, available $\mathrm{P}$ increased by 53.8 and $33.3 \%$, and available $\mathrm{K}$ increased by 11.7 and $6.1 \%$ under treatments of FYM and gypsum, respectively, than their initial values. In the case of fertilizer, 100, 75, and $50 \%$ of recommended doses showed reduction in soil $\mathrm{pH}$ by $0.30,0.30$, and 0.28 units and in EC by $0.07,0.06$, and 0.05 units, respectively, than their initial $\mathrm{pH}$ value of 7.8 and initial $\mathrm{EC}$ of 0.37 . Application of recommended dose, $75 \%$ of $\mathrm{RDF}$ and $50 \%$ of RDF increased other parameters such as organic carbon by $18.9,15.1$, and $13.2 \%$, available $\mathrm{N}$ by $44.7,31.9$, and $22.0 \%$, available $\mathrm{P}$ by $49.7,34.9$, and $20.5 \%$, and available $\mathrm{K}$ by $11.7,6.9$, and $2.6 \%$, respectively. The nutrients release from decomposing residues of rape, sunflower, and soybean in amended soil under laboratory condition was investigated by Scagnozzi et al. [63] at Pisa, Italy, and reported that total $\mathrm{N}$, available $\mathrm{P}$, exchangeable $\mathrm{K}^{+}, \mathrm{Ca}^{2+}$, and $\mathrm{Mg}^{2+}$ in all the amended samples increased significantly. Generally, the increase in the amounts of these nutrients was maintained until the end of the incubation period; the mineralization of the three crop residues enhanced soil fertility. In amended soil samples, $\mathrm{NH}_{4}-\mathrm{N}$ disappeared within 14 days, while available $\mathrm{N}$ was released as $\mathrm{NO}_{3}-\mathrm{N}$ after 60 days in soybean-treated and after 120 days in rape- and sunflower-treated soil, respectively.

Batish et al. $[18,19]$ conducted an experiment to investigate the effect of residues of the noxious weed Parthenium hysterophorus in soil as well as under laboratory conditions. Soils were infested with different amounts of Parthenium hysterophorus residues to determine the changes in soil chemistry and revealed that the $\mathrm{pH}$ of all the modified soils decreased, whereas the conductivity, organic carbon, and organic matter increased. The amount of sodium and potassium increased, whereas that of zinc decreased. In the soil infested with $4 \mathrm{~g}$ of Parthenium hysterophorus residue, the amount of available nitrogen decreased. Paul et al. [64] summarized that the addition of plant residue in soil results in a rapid (days $0-7$ ) increase of soil $\mathrm{pH}$ due to the association, and particularly oxidation, of added organic anions. This was followed by a gradual (days 7-119) $\mathrm{pH}$ decline attributed to the mineralization and subsequent nitrification of added organic $\mathrm{N}$. The addition of $12.5-25.0 \mathrm{~g}$ of cereal crop residues $/ \mathrm{kg}$ of soil and $6.25-25.0 \mathrm{~g}$ of legume-based pasture residues $/ \mathrm{kg}$ of soil resulted in a net alkalization of the surface $2.5 \mathrm{~cm}$ of soil. The magnitude of such gradients will be particularly large with the return of large quantities of plant residues of high ash alkalinity in soils of relatively low initial $\mathrm{pH}$ and biological activity, and when the surface of the soil is exposed to moistdry cycles.

\section{Conclusion}

A review of the literature clearly indicates that sunflower residue incorporation had the adverse effect on crops due its allelocompounds and reduced the growth and yield. Sunflower residue is usually considered a problem but when managed correctly it can improve soil organic matter dynamics and nutrient cycling, thereby creating a rather favorable environment for plant growth on long-term basis. Sunflower residue contains large quantities of nutrients, and thus the return of sunflower stover to the soil can save a considerable quantity of fertilizers. So, on the basis of the above review it can be concluded that recycling of sunflower residue improves the soil biological, chemical, and physical properties, which may enhance the agricultural sustainability in the near future.

\section{Conflict of Interests}

The authors declare that there is no conflict of interests regarding the publication of this paper.

\section{References}

[1] G. Velu, "Crop response to allelopathic effect of sunflower," Research and Development Reporter, vol. 6, no. 1, pp. 16-21, 1989. 
[2] S. S. Narwal, T. Singh, J. S. Hooda, and M. K. Kathuria, "Allelopathic effects of sunflower on succeeding summer crops. I. Field studies and bioassays," Allelopathy Journal, vol. 6, no. 1, pp. 3548, 1999.

[3] S. S. Narwal, S. Yadava, and S. Gupta, "Allelopathic effects of sunflower on succeeding summer crops. 2. Pot culture and biomass decomposition," Allelopathy Journal, vol. 6, no. 2, pp. 209-226, 1999.

[4] M. K. Schon and F. A. Einhelling, "Allelopathic effects of cultivated sunflower on grain sorghum," Botanical Gazette, vol. 143, pp. 505-510, 1980.

[5] R. C. Babu and O. S. Kandasamy, "Allelopathic effect of Eucalyptus globulus Labill. on Cyperus rotundus L. and Cynodon dactylon L. Pers," Journal of Agronomy and Crop Science, vol. 179, no. 2, pp. 123-126, 1997.

[6] S. R. Dhawan and S. K. Gupta, "Allelopathic potential of various leachate combinations towards SG and ESG of Parthenium hysterophorous Linn," World-Weeds, vol. 3, no. 1, pp. 85-88, 1996.

[7] C. M. Casado, "Allelopathic effect of Lantana camara (Verbanaceae) on morning glory (Ipomoea tricolor)," Rhodora, vol. 97, no. 891, pp. 264-274, 1995.

[8] J. Lydon, J. R. Teasdale, and P. K. Chen, "Allelopathic activity of annual wormwood (Artemisia annua) and the role of artemisinin," Weed Science, vol. 45, no. 6, pp. 807-811, 1997.

[9] D. P. Athanassova, "Allelopathic effect of Amaranthus retroflexus L. on weeds and crops," in Seizième conférence du COLUMA. Journées internationales sur la lutte contre les mauvaises herbes, pp. 437-442, Reims, France, 1996.

[10] J. E. Pratley, P. Dowling, and R. Medd, "Allelopathy in annual grasses," in Wild Oats, Annual Ryegrass and Vulpia: Proceeding of a Workshop Held at Orange, vol. 1, pp. 213-214, New South Wales, Australia, 1996.

[11] M. Eyini, A. U. Maheswari, T. Chandra, and M. Jaykumar, "Allelopathic effects of leguminous plants leaf extracts on some weeds and corn," Allelopathy Journal, vol. 3, no. 1, pp. 85-88, 1996.

[12] U. Batlang and D. D. Shushu, "Allelopathic activity of sunflower (Helianthus annuus L.) on growth and nodulation of bambara groundnut (Vigna subterranea (L.) Verdc.)," Journal of Agronomy, vol. 6, no. 4, pp. 541-547, 2007.

[13] M. P. Isidron, C. D. Iglesias, and H. G. Rodriguez, "Study of the allelopathic effects of residues of maize and sorghum at different physiological stages on crops of economic importance and record of the entomofauna present in sunflower (Helianthus annuus L.)," Centro Agricola, vol. 27, no. 4, pp. 29-32, 2000.

[14] K. Srisa-Ard, "Effects of crop residues of sunflower (Helianthus annuus), maize (Zea mays L.) and soybean (Glycine max) on growth and seed yields of sunflower," Pakistan Journal of Biological Sciences, vol. 10, no. 8, pp. 1282-1287, 2007.

[15] Z. Y. Ashrafi, S. Sadeghi, and H. R. Mashhadi, "Allelopathic effects of sunflower (Helianthus annuus) on germination and growth of wild barley (Hordeum spontaneum)," in Proceedings of the 9th International Conference on Precision Agriculture, pp. 324-336, Denver, Colo, USA, July 2008.

[16] M. S. Pal and N. K. Sand, "Effects of sunflower (Helianthus annuus L.) on growth and yield of succeeding crops," Allelopathy Journal, vol. 17, no. 2, pp. 297-302, 2006.

[17] S. S. Narwal, R. Palaniraj, S. C. Sati, and L. S. Rawat, "Effects of different parts of sunflower (Helianthus annuus) biomass on wheat (Triticum aestivum)," Journal of Ecobiology, vol. 15, no. 5, pp. 371-376, 2003.
[18] D. R. Batish, H. P. Singh, J. K. Pandher, V. Arora, and R. K. Kohli, "Phytotoxic effect of Parthenium residues on the selected soil properties and growth of chickpea and radish," Weed Biology and Management, vol. 2, no. 2, pp. 73-78, 2002.

[19] D. R. Batish, P. Tung, H. P. Singh, and R. K. Kohli, "Phytotoxicity of sunflower residues against some summer season crops," Journal of Agronomy and Crop Science, vol. 188, no. 1, pp. 19-24, 2002.

[20] K. Kaur and K. K. Kapoor, "Effect of incorporation of sunflower residues in soil on germination of mungbean and pearl millet," Environment and Ecology, vol. 17, no. 3, pp. 693-695, 1999.

[21] P. J. Morris and D. J. Parrish, "Effects of sunflower residues and tillage on winter wheat," Field Crops Research, vol. 29, no. 4, pp. 317-327, 1992.

[22] D. S. Gill and K. S. Sandhu, "Studies on allelopathic effect of sunflower (Helianthus annuus) residues on succeeding kharif crops," Indian Journal of Ecology, vol. 20, no. 2, pp. 169-172, 1993.

[23] S. S. Narwal, M. K. Sarmah, and D. P. S. Nandal, "Allelopathic effects of wheat residues on growth and yield of fodder crops," Allelopathy Journal, vol. 4, no. 1, pp. 111-120, 1997.

[24] D. S. Rana, G. Giri, K. S. Rana, and D. K. Pachauri, "Effect of sunflower (Helianthus annuus) residue management on productivity, economics and nutrient balance sheet of sunflowerand maize (Zea mays)-based cropping systems," Indian Journal of Agricultural Sciences, vol. 74, no. 6, pp. 305-310, 2004.

[25] Y. Kaya, M. Şengül, H. Ögüutçü, and O. F. Algur, "The possibility of useful usage of biodegradation products of sunflower plants," Bioresource Technology, vol. 97, no. 4, pp. 599-604, 2006.

[26] P. N. Mangare, S. M. Shendurse, S. G. Matale, and S. P. Nandapure, "Effect of incorporation of crop residue on crop productivity and economics under green gram-sunflower sequence," Green Farming, vol. 2, no. 1, pp. 47-49, 2008.

[27] V. P. Badnur, M. A. Bellakki, and S. I. Tolnur, "Incorporation of sunflower crop residues for integrated nutrient management of rabi sorghum in Vertisol," Karnataka Journal of Agricultural Sciences, vol. 13, no. 3, pp. 733-734, 2000.

[28] D. L. Karlen, M. J. Mausbach, J. W. Doran, R. G. Cline, R. F. Harris, and G. E. Schuman, "Soil quality: a concept, definition, and framework for evaluation," Soil Science Society of America Journal, vol. 61, no. 1, pp. 4-10, 1997.

[29] J. W. Doran and T. B. Parkin, "Defining and assessing soil quality," in Defining Soil Quality for a Sustainable Environment, J. W. Doran, D. C. Coleman, D. F. Bezdicek, and B. A. Stewart, Eds., Soil Science Society of America Special Publication no. 35, pp. 3-21, Soil Science Society of America, Madison, Wis, USA, 1994.

[30] R. P. Dick, "Soil enzymatic activities as in indicator of soil quality," in Definding Soil Quality for a Sustainable Development, J. W. Doran, D. C. Coleman, D. F. Bezdicek, and B. A. Stewart, Eds., pp. 107-124, Soil Science Society of America, Madison, Wis, USA, 1994.

[31] K. Kumar and K. M. Goh, "Crop residues and management practices: effects on soil quality, soil nitrogen dynamics, crop yield, and nitrogen recovery," Advances in Agronomy, vol. 68, pp. 197-319, 1999.

[32] W. J. Wang, J. A. Baldock, R. C. Dalal, and P. W. Moody, "Decomposition dynamics of plant materials in relation to nitrogen availability and biochemistry determined by NMR and wet-chemical analysis," Soil Biology and Biochemistry, vol. 36, no. 12, pp. 2045-2058, 2004.

[33] J. M.-. Johnson, N. W. Barbour, and S. L. Weyers, "Chemical composition of crop biomass impacts its decomposition," Soil 
Science Society of America Journal, vol. 71, no. 1, pp. 155-162, 2007.

[34] E. Handayanto, G. Cadisch, and K. E. Giller, "Nitrogen release from prunings of legume hedgerow trees in relation to quality of the prunings and incubation method," Plant and Soil, vol. 160, no. 2, pp. 237-248, 1994.

[35] J. W. Doran, "Microbial changes associated with residue management with reduce management with reduced tillage," Soil Science Society of America Journal, vol. 44, no. 3, pp. 518-524, 1980.

[36] J. M. Duxbury and R. L. Tate III, "The effect of soil depth and crop cover on enzymatic activities in Pahokee Muck," Soil Science Society of America Journal, vol. 45, no. 2, pp. 322-328, 1981.

[37] W. A. Dick, N. G. Juma, and M. A. Tabatabai, "Effects of soils on acid phosphatase and inorganic pyrophosphatase of corn roots (Zea mays)," Soil Science, vol. 136, no. 1, pp. 19-25, 1983.

[38] T. W. Speir and D. J. Ross, "Biochemical changes with pasture development in a West Coast wet land soil: a note," New Zealand Journal of Science, vol. 26, no. 4, pp. 505-508, 1983.

[39] J. F. Power and J. O. Legg, "Effect of crop residues on the soil chemical environment and nutrient availability," in Crop Residue Management Systems, W. R. Oschwald, Ed., ASA Special Publication, pp. 80-110, American Society of Agronomy, 1978.

[40] T. M. Klein and J. S. Koths, "Urease, protease and acid phosphatase in soil continuously cropped to corn by conventional or no-tillage method," Soil Biology and Biochemistry, vol. 12, no. 3, pp. 293-294, 1980.

[41] R. C. Dalal, "Effect of plant growth and addition of plant residues on the phosphatase activity in soil," Plant and Soil, vol. 66, no. 2, pp. 265-269, 1982.

[42] P. Perucci, L. Scarponi, and M. Businelli, "Enzyme activities in a clay-loam soil amended with various crop residues," Plant and Soil, vol. 81, no. 3, pp. 345-351, 1984.

[43] D. A. Martens, J. B. Johanson, and W. T. Frankenberger, "Production and persistence of soil enzymes with repeated addition of organic residues," Soil Science, vol. 153, no. 1, pp. 53-61, 1992.

[44] R. G. Burns, "Enzyme activity in soil: location and a possible role in microbial ecology," Soil Biology and Biochemistry, vol. 14, no. 5, pp. 423-427, 1982.

[45] D. J. Ross, "Some factors influencing the estimation of dehydrogenase activities of some soils under pasture," Soil Biology and Biochemistry, vol. 3, no. 2, pp. 97-110, 1971.

[46] M. Brzezińska, Z. Stępniewska, and W. Stępniewski, "Soil oxygen status and dehydrogenase activity," Soil Biology and Biochemistry, vol. 30, no. 13, pp. 1783-1790, 1998.

[47] C. P. Vance, C. Uhde-Stone, and D. L. Allan, "Phosphorus acquisition and use: critical adaptations by plants for securing a nonrenewable resource," New Phytologist, vol. 157, no. 3, pp. 423-447, 2003.

[48] A. Gajda and S. Martyniuk, "Microbial biomass C and N and activity of enzymes in soil under winter wheat grown in different crop management systems," Polish Journal of Environmental Studies, vol. 14, no. 2, pp. 159-163, 2005.

[49] K. Kaur and K. K. Kapoor, "Carbon mineralization, microbial biomass and nutrient release pattern during decomposition of sunflower residues in soil," Applied Biological Research, vol. 2, no. 1-2, pp. 39-44, 2000.

[50] H. N. Ravankar, R. Patil, and R. B. Puranik, "Decomposition of different organic residues in soil," PKV Research Journal, vol. 24, no. 1, pp. 23-25, 2000.
[51] K. L. Sharma, K. Srinivas, U. K. Mandal et al., "Kinetics of decomposition of un-conventional farm-based crop residues and their composting and quality monitoring," Communications in Soil Science and Plant Analysis, vol. 38, no. 17-18, pp. 2423-2444, 2007.

[52] Yadvinder-Singh, Bijay-Singh, and J. Timsina, "Crop residue management for nutrient cycling and improving soil productivity in rice-based cropping systems in the tropics," Advances in Agronomy, vol. 85, pp. 269-407, 2005.

[53] R. Ordonez-Fernandez, A. Rodríguez-Lizana, R. Carbonell, P. González, and F. Perea, "Dynamics of residue decomposition in the field in a dryland rotation under Mediterranean climate conditions in southern Spain," Nutrient Cycling in Agroecosystems, vol. 79, no. 3, pp. 243-253, 2007.

[54] M. Corbeels, G. Hofman, and O. van Cleemput, "Nitrogen cycling associated with the decomposition of sunflower stalks and wheat straw in a Vertisol," Plant and Soil, vol. 218, no. 1-2, pp. 71-82, 2000.

[55] M. Jalali, "Phosphorus availability as influenced by organic residues in five calcareous soils," Compost Science and Utilization, vol. 17, no. 4, pp. 241-246, 2009.

[56] S. K. Das, K. L. Sharma, K. Srinivas, M. N. Reddy, and O. Singh, "Phosphorus and sulphur availability in soil following incorporation of various organic residues," Journal of the Indian Society of Soil Science, vol. 43, no. 2, pp. 223-228, 1995.

[57] D. K. Das and A. M. Puste, "Influence of different organic waste materials on the transformation of nitrogen in soils," TheScientificWorldJOURNAL, vol. 1, pp. 658-663, 2001.

[58] V. U. Raut, R. T. Bhowate, and A. G. Waghmare, "Effect of crop residues on nutrient contents in greengram-sunflower cropping sequence," Green Farming, vol. 1, no. 1, pp. 14-19, 2010.

[59] R. Santamaría, M. E. Aguirre, and M. A. Commegna, "Effects of sunflowers hull incorporation on the distribution of water extractable elements in the soil," Agrochimica, vol. 52, no. 4, pp. 243-252, 2008.

[60] M. Jalali and F. Ranjbar, "Rates of decomposition and phosphorus release from organic residues related to residue composition," Journal of Plant Nutrition and Soil Science, vol. 172, no. 3, pp. 353-359, 2009.

[61] Z. Gong, P. Li, B. M. Wilke, and K. Alef, "Effects of vegetable oil residue after soil extraction on physical-chemical properties of sandy soil and plant growth," Journal of Environmental Sciences, vol. 20, no. 12, pp. 1458-1462, 2008.

[62] K. Prasad, R. Pyare, C. P. Verma, and S. Chaudhary, "Effect of soil conditioners and fertilizer application on soil properties with maize residue incorporation under maize-wheat sequence," Plant Archives, vol. 5, no. 2, pp. 421-427, 2005.

[63] A. Scagnozzi, A. Saviozzi, R. Levi-Minzi, and R. Riffaldi, "Nutrient release from decomposing crop residues in soil: a laboratory experiment," The American Journal of Alternative Agriculture, vol. 12, no. 1, pp. 10-13, 1997.

[64] K. I. Paul, A. S. Black, and M. K. Conyers, "Effect of plant residue return on the development of surface soil pH gradients," Biology and Fertility of Soils, vol. 33, no. 1, pp. 75-82, 2001. 


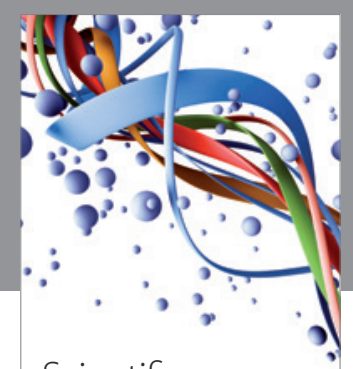

Scientifica
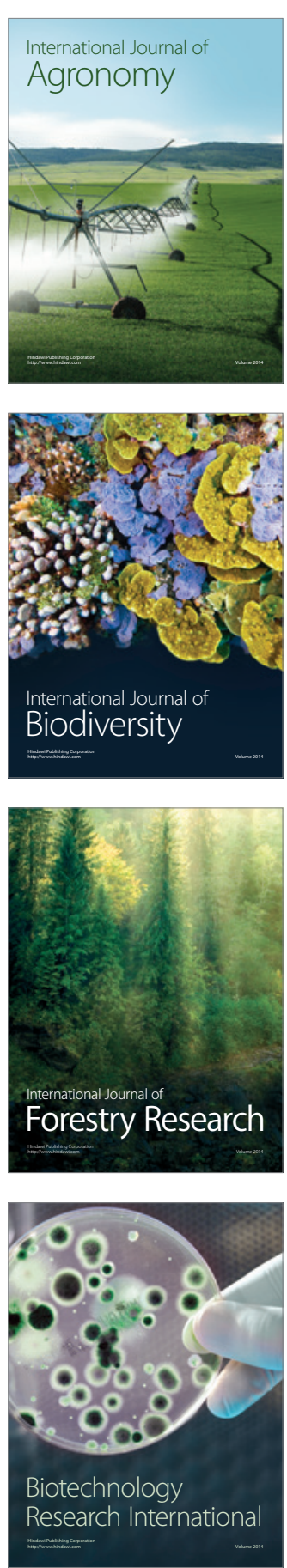
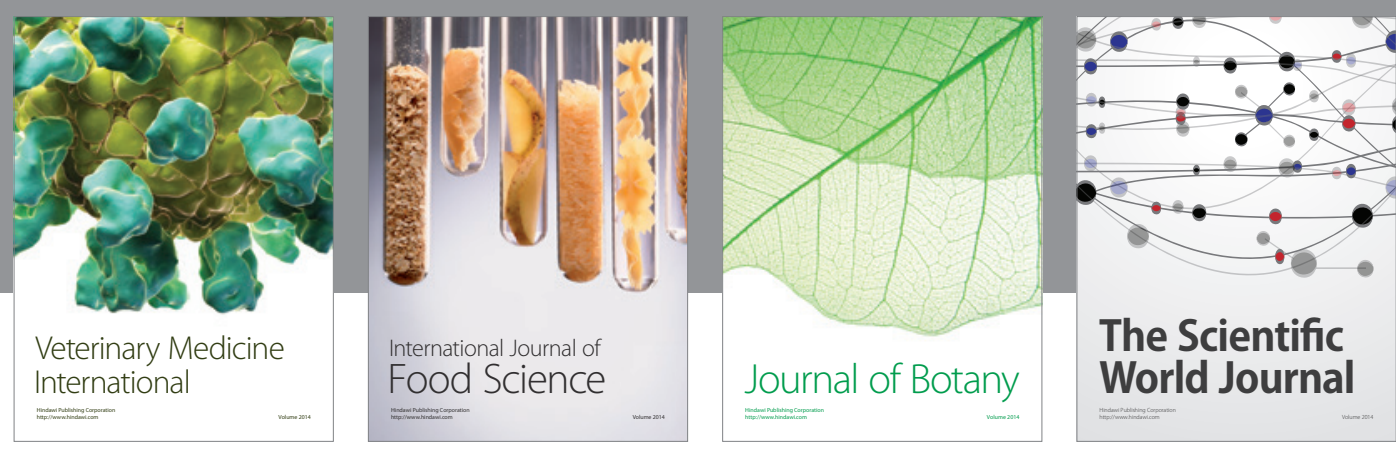

The Scientific World Journal
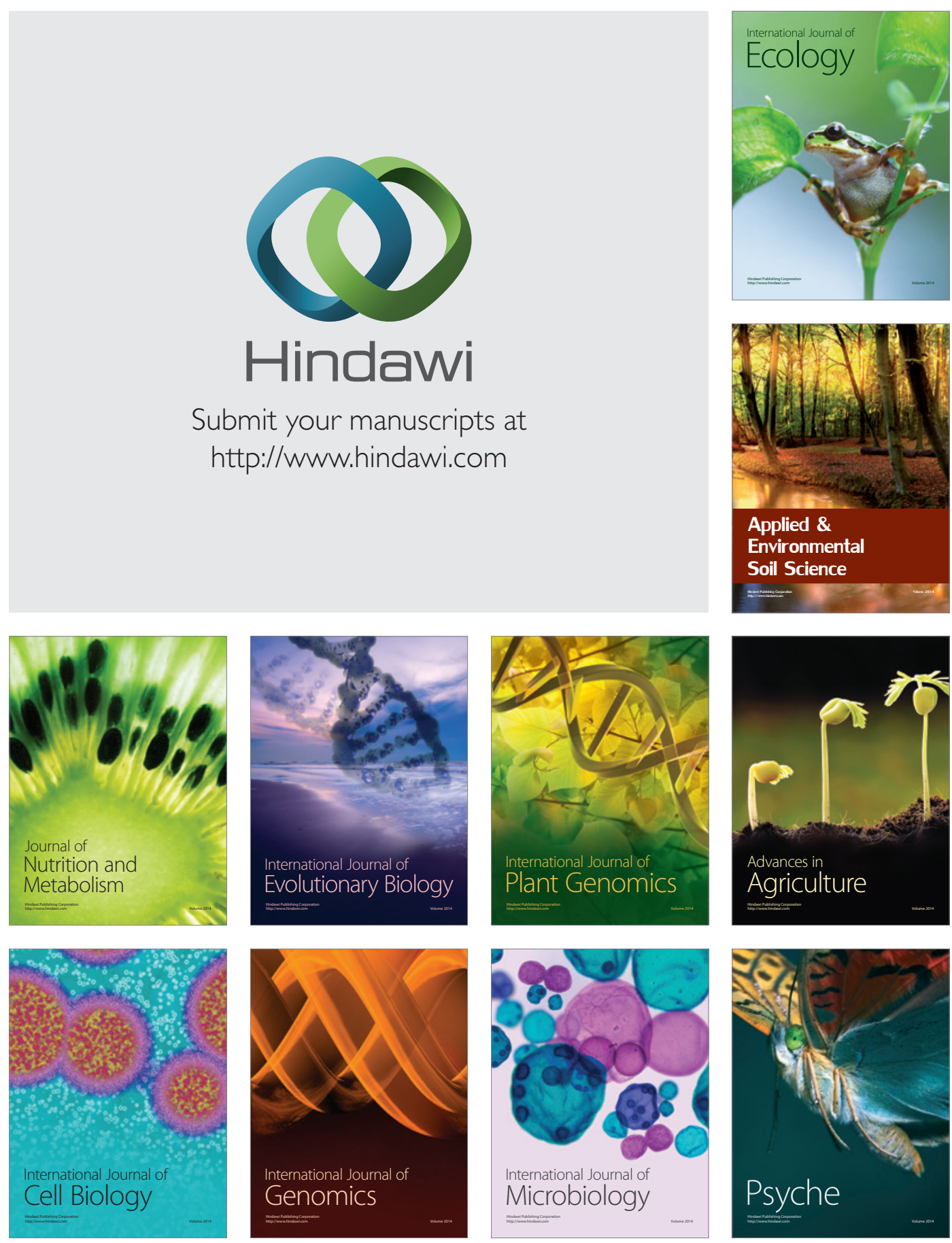